Article

\title{
Social-Ecological Resilience as Practice: A Household Perspective from Agua Blanca (Ecuador)
}

\author{
Esteban Ruiz-Ballesteros ${ }^{1, *}$ and Paulino Ramos-Ballesteros ${ }^{2}$ \\ 1 Department of Social Anthropology, Psychology and Public Health, Universidad Pablo de Olavide, \\ 41013 Sevilla, Spain \\ 2 FLACSO Ecuador, Quito 170201, Ecuador; paubolson@gmail.com \\ * Correspondence: eruibal@upo.es
}

Received: 13 August 2019; Accepted: 9 October 2019; Published: 15 October 2019

\begin{abstract}
Within a social-ecological system (SES), households develop specific practices, the logics of which are not derived directly or exclusively from higher levels (community, social-ecological system). This article advocates paying closer attention to this micro level of social-ecological analysis in order to gain a better understanding of the SES dynamic and its resilience. It explores the links between the functioning of the SES and human agency by means of a household approach (economic strategies, collective participation). To illustrate this proposal, an ethnographic case study was conducted in Agua Blanca, a community in Ecuador. The evolution and current situation of the SES, its desirability and the factors that support its resilience, as well as the practices of the most recently formed households, are analysed. This analytical proposal affords a more consistent understanding of the heterogeneous social-ecological interactions within an SES (plasticity), showing how resilience is inherently linked to practices. For this purpose, ethnographic methodology offers an outstanding tool.
\end{abstract}

Keywords: ethnography; household; human agency; practices; social-ecological resilience

\section{Introduction}

The evolution of a social-ecological system (SES) depends on the development of multiple biophysical and socio-economic drivers that are fundamentally conditioned by human action. Human beings play a leading role in the adaptability, transformability and resilience of an SES, be it in the determination of their desirable configurations [1,2], the shaping of systems of governance [3-5] or the legitimation of the trade-off between socioeconomic and biophysical phenomena and processes [6]. These matters are closely linked with power relations, the analysis of which has brought about a "political turn" in social-ecological resilience [6-14].

However, this "political turn" appears to be too strongly conditioned by structural approaches or perspectives linked to political ecology $[15,16]$, which fosters an excessively mechanical consideration of human behaviour.

Although it is important to bear in mind that power relations impose a framework of social-ecological interactions [7] affecting human behaviour within the SES, we must not forget that, often, everyday human practices reinterpret and transform this framework. Hence, although the community and its institutions-as political contexts-are the most relevant references to understand resource management in an SES [17], households must also be taken into account because of the former's internal heterogeneity [11]. In the context of the community, households play a leading role in the production of resources, social reproduction, and the consumption of goods and services. If we are looking to understand socio-ecological functioning, the household constitutes a more operational and environmentally significant unit than the individual. In addition to the community level, the most 
relevant decisions with regard to production and consumption strategies are made within the context of households. Furthermore, household configurations are a fundamental component in understanding the demographics, the patterns of human-environment relations and the social integration of members of the community.

In the context of households, specific practices develop, the logic of which is not extrapolated from that of other higher levels (community, SES). Unless we pay proper attention to this micro level of social-ecological analysis, we will not fully understand the dynamic of the SES and its resilience.

In accordance with this analytical need, this article explores the advantages of interlinking these two levels of analysis: social-ecological system and household, the main objects of social-ecological resilience and development resilience [17]. The aim is to link the functioning of the SES with human behaviour (agency) expressed through the household's performance, which allows us to explore how resilience is linked to practices. Households and SES are not separate distinct dimensions, rather, they are integrated into the SES framework [18]. For the purposes of this paper, however, they are analysed separately, in order to improve our understanding of the practices associated with resilience.

To explore the advantages afforded by this analytical proposal, we propose an ethnographic case study conducted in Agua Blanca, a community in Ecuador that has engaged particularly with community-based tourism within a natural protected area.

The next section sets out the theoretical framework in which our proposal is grounded, before describing the methodology used. We shall then present the case study itself, analysing the evolution and current situation of the SES, its desirability and the factors that support its resilience. This exercise will give rise to a household approach focusing on the most recently formed households in the community, in order to clarify the extent to which their tactics, practices and expectations contribute or not—and how—to the resilience of the SES. This household approach will eventually focus on a practice of particular significance within the SES: charcoal-making. The discussion will then be followed by a section that sets out the conclusions reached regarding the potential and limits of this analytical perspective.

\section{Social-Ecological Resilience from a Phenomenological Perspective}

Alongside a structural/systemic approach to resilience, we require a perspective that encompasses human agency and shows us everyday forms of resilience [19-21]. This involves analysing specific practices of individuals and households, and not remaining exclusively at the level of the community as a whole as a socio-political structure that subsumes the agency of its members. From this perspective, human agency is manifested not only through collective decisions recognised explicitly as 'policies', but also at the level of individual households, when they make decisions about everyday activities and practices that materialise human/environment relations. By analysing practices, we can focus on a micro level in order to study on another scale the development and evolution of the SES and its capacity for resilience. This analytical perspective can play a crucial role in the development of guidelines and norms within frameworks of governance [22-24].

An SES structure can have a desirable configuration that strives for resilience. This configuration has a set of key drivers as well as socio-cultural and biophysical capacities that reinforce its resilience [1]. From a phenomenological perspective-practices and human agency—we are focusing on the behaviour of subjects within the context of their households, and ascertaining whether these behaviours, in the form of activities, are coherent with the drivers that determine the desirable configuration of the SES and whether they effectively reinforce its capacity for resilience when faced with potential processes of transformation.

The aim is not to avoid the study and analysis of the parameters, drivers, and biophysical and political processes that frame the structural evolution of the SES. Rather, the research presented here intends to complement it, by contrasting it with a micro-dimension (practices) that is particularly strategic when it comes to refining our knowledge and evaluation of the SES and its social-ecological 
resilience. From this perspective, practices can be understood as an expression of resilience. In other words, resilience is embodied in the everyday practices of people.

This phenomenological perspective, which focuses on social practices, can be particularly useful for highlighting the dynamic of the SES, since it allows us to identify, using an empirical approach, tactics and strategies $[25,26]$, as well as innovations or continuities that cannot be deduced from an analysis of the socio-political structure (community, institutions, rules), and assessing its potential effects on the biophysical drivers.

These practices can be very varied and are always context dependent. But they tie in with basic factors for social-ecological resilience: diversity of productive activities [27,28], learning capacity [29], collective participation, and place attachment [30].

As a methodological strategy, this phenomenological analysis of resilience can take shape by means of a household approach in order to study empirically the practices and trajectories that embody human-environment interaction in the form of activities (productive, symbolic), or patterns of collective participation within the community. Analysis of the practices developed within households should verify the extent to which and how the SES can be maintained in a desirable configuration (adaptability), and the way in which resilient attitudes are expressed in people, which points to their capacity to cope with substantial changes in the SES (transformability). This level of microanalysis should furnish a better understanding of the dynamic of an SES.

Any political-structural analysis would determine that the framework of socio-environmental interactions in which a SES operates is grounded in high institutional-normative pressure-by way of environmentality [31]. But, to reflect on its resilience, a more dynamic and phenomenological perspective is required, focusing on human practices and attitudes (individuals, households), which shed light on observable tendencies. The evolution of the SES is related with its structure and power system, but also with the human agency of its members, and that agency is grounded in their practices, attitudes and expectations. Therefore, to gain a more in-depth understanding, we should pull our analytical focus in from the community level to the household level, since this is the context in which individuals develop their strategic practices in relation to production, consumption of resources, and social reproduction. When doing so, it is important to bear in mind the decision-making processes that occur within households, along with the evolution and changes these households might undergo.

Specifically, we shall be focusing on the most recently constituted households since we understand that, through their practices, these households will shape the near future of the SES in a more significant way. Within a community, as households gradually form, they are integrated into a hegemonic framework of human-environment interactions, whilst at the same time expressing a greater capacity for social and economic innovation. Through their economic activities, patterns of social interaction, and expectations (desires, values), new households will take the SES in one direction or another, according to its structural evolution but not as a mechanical reflection thereof. Analysing their economic - exploitation of resources—and socio-political—community participation-practices and their coherence with the factors that make the configuration of the SES desirable, becomes a strategic approach to understanding the shaping of social-ecological resilience.

In this regard, by interlinking the structural (social-ecological system) and phenomenological (practices of new households) analysis, we should gain a better understanding of the configuration of the SES and its resilience.

\section{Methods}

The research presented here is an exploratory case study [32,33] of the evolution of a social-ecological system and its resilience. To this end, an ethnographic methodology is felt to be particularly appropriate, since it allows us to study the structural configuration of an SES as well as the micro- and everyday-dimensions of resilience (practices) (see research design, Table 1). 
Table 1. Research design. SES: social-ecological system.

\begin{tabular}{|c|c|c|c|}
\hline Aim & Focus on & Focus from & \multirow{3}{*}{$\begin{array}{l}\text { Demographic behaviour } \\
\text { Household economy } \\
\text { Local knowledge/learning capacity } \\
\text { Patterns of collective participation in } \\
\text { the community (governance) } \\
\text { Evidence of place attachment } \\
\text { Future outlook in the face of possible } \\
\text { crises and structural changes }\end{array}$} \\
\hline \multirow[t]{2}{*}{$\begin{array}{l}\text { To explore how resilience } \\
\text { is linked to practices. }\end{array}$} & $\begin{array}{l}\text { 1.- Desirable SES configuration (main } \\
\text { biophysical and socio-cultural } \\
\text { drivers):deforestation (charcoal making) } \\
\text { demographic evolution } \\
\text { food sovereignty } \\
\text { tourism market }\end{array}$ & \multirow[t]{2}{*}{$\begin{array}{l}\text { human agency from a } \\
\text { household perspective }\end{array}$} & \\
\hline & $\begin{array}{l}\text { 2.- Social resilient capacities: } \\
\text { diversity of productive activities } \\
\text { learning capacity } \\
\text { collective participation } \\
\text { place attachment }\end{array}$ & & \\
\hline
\end{tabular}

A longitudinal ethnographic study was conducted over extensive and intensive periods between 2006 and 2018, allowing us to track the evolution of the SES over the course of a sufficiently significant period of time to understand its bio-physical and socio-cultural functioning. Specifically, intensive onsite fieldwork was conducted in 2006 (two months), 2007 and 2008 (one and a half months each year), and 2009 (one month). Subsequently, the community's evolution was monitored extensively, based on secondary sources and sporadic contact (2010 to 2015), and in 2016 direct contact was re-established through a two-week stay, before culminating the fieldwork in 2018 by means of a one-month stay.

Together with classic ethnographic sources and techniques (secondary documentation, participatory observation, interviews, focus groups), with regard to the subject matter examined here, it has been particularly important to conduct two subsistence surveys in all the community's households (2007 and 2018), providing us with precise information about productive practices (human-environment interactions) and their evolution. By conducting several rounds of interviews (specifically in the fieldwork campaigns conducted in 2006, 2008 and 2018) and carrying out participatory observation throughout the research process, we have gained knowledge about the rest of the practices, processes and strategic phenomena within the SES: demographic behaviour, local knowledge, learning capacity, forms of organisation and community participation (governance), place attachment, and future outlook in the face of possible crises and structural changes. Close attention must be paid to the way in which all of this is structured and interlinked, leading to the emergence of a dynamic and relational resilience [34].

Taking into account that the current regime of the SES in Agua Blanca was established at the beginning of this century (see below), we have determined that the concept of 'new households' refers to those set up since the year 2000. These new households are made up of young individuals who follow the habitual tendency in the community of starting a family, although this does not imply specific patterns in household building. These groups (18) account for $27 \%$ of the total number of households at present, and to analyse them, we have focused on those located in the main population nucleus (13). These new households were also the subject of the subsistence surveys referred to above (2017 and 2018) and all the fieldwork conducted since 2006 in the community. In addition, and in direct relation with the subject of this paper, during the fieldwork campaign carried out in $2018,50 \%$ of these households were subject to more intense monitoring that included individualised observation and specific open-ended interviews (per couple), which allows us to analyse in depth their trajectory (micro-biography), demographic behaviour, productive practices, local knowledge/learning capacity, participation in the community (governance), place attachment, and attitudes towards the future and in the event of a crisis in the SES.

\section{Results}

\subsection{Agua Blanca: Social-Ecological System (SES) Configuration and Resilience Capacity}

The SES referred to here as Agua Blanca encompasses 9000 ha of collective property/usufruct, inhabited by a community of 292 inhabitants (2018). This territory is located within the Machalilla 
National Park (coastal area of Ecuador) and comprises three ecological areas: Buenavista river valley, tropical dry forest, and cloud forest.

This SES began to take shape in the late 19th Century with the establishment of a hacienda, carrying out extraction and farming activities that fostered an acute process of environmental decline until it eventually disappeared in the 1970s. The creation of a national park (1979) and the configuration of the community (after the hacienda farming estate went bankrupt) ushered in a period of transition that lasted until the mid-1980s. This transition was characterised by major socio-environmental conflict around the production of charcoal, which had become the community's main productive activity. The conflict was resolved through an agreement that contemplated the development of community-based tourism, recognition of communal territory, and the eradication of extraction activities (hunting, extraction of timber, charcoal-making) [35-37] (See Table 2).

Table 2. Evolution of the Agua Blanca SES (19th-21st Century).

\begin{tabular}{|c|c|c|c|}
\hline & $\begin{array}{l}\text { Initial Regime } \\
\text { End C19th-1970s }\end{array}$ & $\begin{array}{c}\text { Transition } \\
\text { mid1970s-mid1980s }\end{array}$ & $\begin{array}{l}\text { Current Regime } \\
\text { mid1980s-Present }\end{array}$ \\
\hline Logic of the SES & $\begin{array}{l}\text { Agro-capitalism } \\
\text { extractivism }\end{array}$ & Extractivism & $\begin{array}{l}\text { Conservation, } \\
\text { Tourism }\end{array}$ \\
\hline Initial turning point & $\begin{array}{l}\text { Beginning of the } \\
\text { capitalist exploitation of } \\
\text { ivory palm trees. } \\
\text { Hacienda }\end{array}$ & $\begin{array}{l}\text { Severe drought } \\
(1965 / 1985) ; \\
\text { Bankruptcy of the } \\
\text { hacienda; Creation of the } \\
\text { National Park }\end{array}$ & $\begin{array}{l}\text { Agreement } \\
\text { park/community; } \\
\text { Cultural and natural } \\
\text { heritagisation; } \\
\text { Community-based } \\
\text { tourism; Recognition of } \\
\text { communal territory }\end{array}$ \\
\hline Governance & Monocentric (Hacienda) & Polycentric (disjointed) & $\begin{array}{l}\text { Multilevel adaptive } \\
\text { co-management } \\
\text { national } \\
\text { park/community }\end{array}$ \\
\hline Model of production & $\begin{array}{l}\text { Farming: livestock, } \\
\text { coffee. } \\
\text { Extraction: ivory palm } \\
\text { and timber; charcoal, } \\
\text { Archaeological remains }\end{array}$ & $\begin{array}{l}\text { Extraction: charcoal, } \\
\text { hunting, timber, } \\
\text { Archaeological remains }\end{array}$ & $\begin{array}{l}\text { Tourism } \\
\text { Gathering, } \\
\text { picking/livestock and } \\
\text { agricultural subsistence } \\
\text { farming }\end{array}$ \\
\hline $\begin{array}{l}\text { Main biophysical and } \\
\text { socio-cultural effects }\end{array}$ & $\begin{array}{l}\text { Social-ecological } \\
\text { transformation according } \\
\text { to market demand. } \\
\text { Immigration of day } \\
\text { labourers with no land }\end{array}$ & $\begin{array}{l}\text { Worsening of } \\
\text { deforestation effect on } \\
\text { the river valley (charcoal) } \\
\text { and the cloud forest } \\
\text { (timber). } \\
\text { Emigration }\end{array}$ & $\begin{array}{l}\text { Biophysical recovery: } \\
\text { elimination and } \\
\text { reduction of extraction } \\
\text { activities (timber, } \\
\text { hunting, charcoal). } \\
\text { Demographic regulation }\end{array}$ \\
\hline Desirability & $\begin{array}{l}\text { Desirable for the } \\
\text { hacienda and day } \\
\text { labourers. } \\
\text { Environmentally } \\
\text { unsustainable }\end{array}$ & $\begin{array}{l}\text { Desirable for inhabitants, } \\
\text { undesirable for National } \\
\text { Park. Environmentally } \\
\text { unsustainable }\end{array}$ & $\begin{array}{l}\text { Desirable regime for } \\
\text { Park and community. } \\
\text { Negotiation and } \\
\text { trade-off. } \\
\text { Towards sustainability }\end{array}$ \\
\hline
\end{tabular}

The current configuration of the SES is understood to be desirable by conservation agents and the community itself, recognising that an appropriate balance has been achieved between biodiversity, ecosystem services, and local development. On the one hand, the conservation agents acknowledge the recovery of the forest and fauna, as well as a tolerable level of extraction with regard to biophysical resources. On the other, the inhabitants of the community have a very positive opinion of the standard of living achieved through tourism. Tourism has become the main local activity, experiencing a dramatic increase in visitors and revenue. However, with the community-based tourism model in place, internal socio-economic differentiation has not increased. In fact, the community Gini index was 
0.223 in 2006 and 0.233 in 2017, indicating an insignificant increase in inequality, which reinforces the positive effect of this activity on local life (increasing quality of life without driving up inequality).

This circumstance does not preclude the existence of different trade-offs between socioeconomic and biophysical elements (consumption, mobility, waste ... ), as well as the constant need to control and negotiate human activities in the environment. Hence, multilevel adaptive co-management is crucial to understanding the SES, with the community playing a very prominent role owing to its level of self-government (rules, practices, decisions) in managing the territory as commons [37].

The main drivers of the SES are: climate change and its effect on precipitation patterns, deforestation of the river valley as a consequence of charcoal-making, the demographic evolution of the community, food sovereignty, and the tourist market. The sustainability of the SES combines socioeconomic development and environmental conservation by: (a) controlling the population (growth), (b) reducing the role of biophysical resources in the generation of monetary revenue (timber, charcoal, picking/harvesting ... ), (c) promoting community-based tourism to generate monetary revenues without creating exclusive dependency, and (d) moderating the need for monetary revenues through self-supply consumption (vegetable gardens). Hence the strategic prominence is gained by three specific activities: tourism, charcoal-making, and agriculture.

Over the past twelve years, the local population has increased by $13 \%$. However, emigration is no longer a demographic regulator. The birth rate has dropped dramatically, and unlike the case a few decades ago, the community is now able to absorb its entire population (people from outside the community are not allowed to settle within this territory). Between 2006 and 2018, the number of tourists has trebled (from 7645 in 2005 to 24,251 in 2018). Half of the households in this community earn $40 \%$ of their annual income through tourism. However, tourism in Agua Blanca consists of a guided tour lasting several hours that takes tourists around the communal territory. Hardly any visitors spend the night there, which minimises the impact of this activity on the environment and local society. The economic importance of picking and gathering wild fruits and vegetables, and charcoal making, has declined dramatically, although not disappeared completely. However, $75 \%$ of households are involved in subsistence agriculture for their own consumption. (See Table 3)

Table 3. Comparative data in the community (2006/2017).

\begin{tabular}{cccc}
\hline & $\begin{array}{c}\mathbf{2 0 0 6} \\
\text { Total Households }\end{array}$ & $\begin{array}{c}\mathbf{2 0 1 7} \\
\text { Total Households }\end{array}$ & $\begin{array}{c}\text { 2017 } \\
\text { New Households }\end{array}$ \\
\hline \% gathering income & 20.4 & 2.5 & 2.2 \\
\% livestock income & 5.8 & 8.5 & 8.9 \\
\% charcoal income & 10.5 & 7.1 & 18.8 \\
\% tourism income & 39.5 & 46.7 & 53.1 \\
\% construction income & 4.5 & 9.7 & 11 \\
\% family grant income & 4.2 & 6.1 & 1.9 \\
\% others income & 14.7 & 19.3 & 2.4 \\
children/household & 2.3 & 2.1 & 1.8 \\
vegetable gardens & 4.1 & 4.3 & 5.1 \\
number activities/year per household & $56 \%$ & $74 \%$ & $77 \%$ \\
\hline
\end{tabular}

The growing importance of tourism has not eroded the diversification of productive activities within the community as a whole or within households. Whereas in the mid-1980s local economic activities were largely limited to charcoal-making and livestock farming, today there is much greater diversity. Since 2006, local households have, on average, engaged in more than four different productive activities over the course of the year.

This evolution is not possible without the development of a multilevel adaptive co-management system, which involves compact institutional architecture for the community (assembly, activity/resource-specific committees), a whole raft of rules and regulations, and an effective system of 
horizontal control [35,37]. All are set within a framework of collective ownership of the territory and sole rights to its use and exploitation, assigned to the community and guaranteed by the State.

This SES cannot be adequately understood without taking into consideration the multiple external influences and regional interactions to which it is subject, which can be summarised in terms of three major spheres. Firstly, the general climatic dynamic of the region itself, which conditions above all the rainfall and, therefore, animal life and plant cover in this area. Secondly, the influence of the State, which not only dictates the degree of self-governance the community can enjoy, but also, more precisely, conditions human-environment relations through the national park regulations. Finally, the market has a major impact at different levels: (1) the inhabitants of the community participate in the region's labour market, particularly with regard to construction, (2) certain products-for example charcoal-are subject to fluctuations in external demand, since they are sold outside of the community, and (3) the local economy's main external dependence is tied to the flow of tourism itself, which depends wholly on the national park's ability to attract visitors. The community's tourist offer is not independent, but instead is a sub-product of the tourist offer available at the Machalilla National Park, where the community is situated. This whole series of external interactions contextualises the functioning of the SES.

This SES, as well as presenting a desirable configuration, is also developing a capacity for resilience, which is mainly manifested in the community and individual pluri-activity, as well as in the stripped-back system of local participatory governance with multilevel articulation [36].

\subsection{The Practices of New Households for Social-Ecological Resilience}

At this point we have the elements to define how the SES operates at a structural level and indicate the main factors underpinning its resilience. However, to gain a more in-depth understanding of SES dynamic and its resilience, we need to pull our analytical focus in from the community level to the household level. In doing so, we will analyse how and to what extent the practices of new households tie in with the determining factors of resilience in Agua Blanca. These factors, as shown previously (Table 1), are linked, on the one hand, with the biophysical and sociocultural drivers that condition the desirable configuration of the SES, and on the other hand, with the development and consistency of social resilience capacities. Within the context of this research, these factors can be specified as demographic behaviour, household economy (diversity of productive activities), patterns of collective participation in the community (governance), local knowledge/learning capacity, place attachment, and future outlook in the face of possible crises and structural changes.

All of these factors, beyond an analytical and abstract consideration, are embodied empirically in the specific practices of households in Agua Blanca, which give meaning and relevance to the functioning of the SES. At a micro level, we are considering the decisions made by household members in relation, for example, to family planning, their choice of economic activity, or their effective and symbolic bond to the place they inhabit. This constitutes an evident display of human agency that ultimately determines the resilience of the SES by affecting its most important drivers and its capacity for resilience. In this case, the most relevant issue from an analytical perspective is to evaluate the way and extent to which the decisions made by households converge or diverge with regard to the factors that keep the SES in its current desired configuration.

Although the population of Agua Blanca has risen in recent years, the demographic behaviour of new households is slowing that trend down: compared to the average of 2.1 children per couple for the community as a whole, these new households have, on average, 1.8 children per couple and also state with certainty that they will not have any more. This is a very conscious decision that was conveyed to us in all the interviews conducted. Young couples use contraceptive methods and plan their families in accordance with their prospects regarding their desires/possibilities of consumption and their commitment to the future education of their children.

As for productive activities-a basic practice in relation with the environment-they present two fundamental differences with regard to the community as a whole: (1) they almost triple the 
average earnings generated through charcoal and (2) they substantially accentuate the role of tourism in their household economies (see Table 4). Furthermore, their average number of annual activities per household is 5.1 , in contrast to 4.3 for the community as a whole. These data paint a contradictory picture: in contrast to the protagonism of tourism and the high levels of pluri-activity, there seems to be a regression with regard to the practice of charcoal making.

The production of charcoal is one of the fundamental drivers of the SES. In fact, its progressive eradication has framed the transformation of the SES, and a desirable status has been achieved, which strives for resilience. In the 80s, charcoal representing the primary source of earnings for almost all the households in the community, with a production of around 14,000 sacks a year. By 2017, this number had fallen to 2253.

The data pertaining to new households, as a collective, highlight the internal heterogeneity of the community. However, if we focus our analytical lens on individual new households, we see that there is also considerable internal diversity.

Table 4. Data for new households.

\begin{tabular}{|c|c|c|c|c|c|c|c|c|c|}
\hline Household & Children & $\begin{array}{l}\text { Vegetable } \\
\text { Garden }\end{array}$ & $\begin{array}{l}\text { \%Gathering } \\
\text { Income }\end{array}$ & $\begin{array}{l}\text { \%Livestock } \\
\text { Income }\end{array}$ & $\begin{array}{l}\text { \%Charcoal } \\
\text { Income }\end{array}$ & $\begin{array}{l}\text { \%Tourism } \\
\text { Income }\end{array}$ & $\begin{array}{l}\text { \%Construction } \\
\text { Income }\end{array}$ & $\begin{array}{l}\text { \%Family } \\
\text { Grant }\end{array}$ & $\begin{array}{l}\text { \%Others } \\
\text { Income }\end{array}$ \\
\hline $\mathrm{H} 1$ & 2 & yes & 1 & 2 & 0 & 88 & 9 & 0 & 0 \\
\hline $\mathrm{H} 2$ & 3 & yes & 2 & 9 & 0 & 84 & 5 & 0 & 0 \\
\hline $\mathrm{H} 3$ & 3 & no & 0 & 9 & 0 & 79 & 8 & 0 & 5 \\
\hline $\mathrm{H} 4$ & 1 & yes & 0 & 21 & 0 & 75 & 4 & 0 & 0 \\
\hline H5 & 2 & yes & 6 & 4 & 0 & 72 & 8 & 11 & 0 \\
\hline H6 & 2 & no & 0 & 13 & 0 & 71 & 8 & 0 & 5 \\
\hline $\mathrm{H} 7$ & 1 & yes & 2 & 1 & 0 & 70 & 8 & 0 & 19 \\
\hline $\mathrm{H} 8$ & 2 & yes & 7 & 10 & 14.5 & 48 & 6 & 10 & 0 \\
\hline $\mathrm{H} 9$ & 1 & yes & 0 & 4 & 6.7 & 43 & 46 & 0 & 0 \\
\hline $\mathrm{H} 10$ & 3 & no & 3 & 6 & 63.8 & 8 & 3 & 16 & 0 \\
\hline H11 & 1 & yes & 3 & 18 & 72.7 & 0 & 6 & 0 & 0 \\
\hline $\mathrm{H} 12$ & 2 & yes & 0 & 8 & 84.2 & 0 & 7 & 0 & 0 \\
\hline H13 & 1 & yes & 7 & 8 & 64.8 & 0 & 21 & 0 & 0 \\
\hline TOTAL & & & 2.2 & 8.9 & 18.8 & 53 & 11 & 1.9 & 2.4 \\
\hline
\end{tabular}

Seven of these new households generate income chiefly through tourism and do not make any charcoal whatsoever. However, for four of these households, charcoal is their primary activity, and they are not involved in tourism in any way. Furthermore, two households pursue a mixed strategy, with tourism as the main activity. They all partake in livestock breeding or construction to a greater or lesser degree, and ten of the households engage in subsistence agriculture for their own consumption. New households that engage in tourism as their primary activity are more dependent on it than the rest of the households in the community that are dedicated mainly to tourism. Furthermore, of the 10 households that make charcoal within the community as a whole, four are new households, and for them this activity accounts for $71 \%$ of their earnings. For the remaining six households, charcoal only represents $62 \%$ of their earnings. Therefore, the new households are at one and the same time more dependent on tourism and charcoal than the rest of the community, and this is in spite of the fact that they participate in a greater number of productive activities. This circumstance describes a paradox in the behaviours and decisions (human agency) of new households with regard to the community as a whole, which we will return to later on.

Levels of participation in community governance (Table 5) are very high among new households. They regularly attend assembly meetings-the highest community governing body-since their attendance also gives them certain rights with regard to community activities and services. However, they also hold prominent positions on the different committees as well as the community's governing council. Of particular note are the higher participation levels found among households that engage in tourism as their primary activity. In this respect, it is necessary to underscore the protagonism of new households in the socio-political functioning of the community. Their participation and initiatives play a strategic role in local organisation. The members of these households (chiefly men but also the more active women in the community) feel a strong sense of commitment to collective participation. 
Table 5. Participation of new households in governance.

\begin{tabular}{|c|c|c|c|c|}
\hline Household & $\begin{array}{l}\text { Positions on } \\
\text { Committees }\end{array}$ & $\begin{array}{c}\text { Community's } \\
\text { Governing Council }\end{array}$ & $\begin{array}{l}\text { Assembly } \\
\text { Attendance }\end{array}$ & $\begin{array}{l}\text { Main Household } \\
\text { Activity }\end{array}$ \\
\hline $\mathrm{H} 1$ & $x$ & & $x$ & $\mathrm{~T}$ \\
\hline $\mathrm{H} 2$ & $x$ & & $x x$ & $\mathrm{~T}$ \\
\hline $\mathrm{H} 3$ & $x$ & $x$ & $x x$ & $\mathrm{~T}$ \\
\hline $\mathrm{H} 4$ & $x x$ & $x x$ & $x x$ & $\mathrm{~T}$ \\
\hline H5 & & & $x$ & $\mathrm{~T}$ \\
\hline H6 & $x$ & $x$ & $x$ & $\mathrm{~T}$ \\
\hline $\mathrm{H} 7$ & $x$ & & $x$ & $\mathrm{~T}$ \\
\hline H8 & & & $x$ & M \\
\hline H9 & & $x$ & $x x$ & M \\
\hline H10 & & & $\mathrm{x}$ & $\mathrm{C}$ \\
\hline H11 & & & & $\mathrm{C}$ \\
\hline H12 & & & $x x$ & $\mathrm{C}$ \\
\hline H13 & & & $x$ & $\mathrm{C}$ \\
\hline
\end{tabular}

Main household activity: T (tourism); C (charcoal); M (mixed). Each x represents a member of the household.

When it comes to developing resilience, a firm understanding of the environment and the capacity to learn are of strategic importance [38,39]. In the case of new households in Agua Blanca, these two aspects are sufficiently developed by virtue of: (1) the level of pluri-activity found among these groups, which guarantees consistent knowledge of the resources available from the environment and the ways in which they can be harnessed (from picking and gathering different wild fruits and vegetables to working in construction outside of the community). (2) Practically all of them have experience as migrants and they know about the wider world outside of the community, and (3) those who engage in tourism have demonstrated their capacity to learn as tour guides, in the production of arts and crafts, and other services (including $40 \%$ of women).

Without exception, they all state that they have decided to stay in the community as the result of a rational and conscious choice, having compared this life with their experiences as migrants in cities elsewhere in Ecuador. The arguments they put forward mention elements such as peace and quiet, safety, and the availability of common resources. Their appreciation of the quality of life offered in Agua Blanca leads them to develop a remarkable place attachment.

“J: Out there it's completely screwed up. If you don't have work, you don't have anything. Here you have animals, or friends who share with you (... ) M: I appreciate everything. Children grow up surrounded by nature, they are free to walk around here. I like going to the city for a little while, one, two, or three days, but that's it." (J and M, H12)

“S: Whatever happens, I'm not leaving Agua Blanca, because I don't see myself living in a city ( ... ) A: I don't like going to the city, not even for a visit. And definitely not to live there. Here we can live on very little money and we are all in it together." (S and A, H4)

With regard to possible substantial changes to the SES, particularly a potential crisis in tourism, they recognise that it would be a traumatic situation for the community: "The community would go back to square one, the way it was before: charcoal-making, a bit of livestock farming, there wouldn't be as many resources, and we wouldn't be able to improve the housing ... we would have to leave" (S, H4). Emigration is the solution that they foresee for the community as a whole, but, paradoxically, they express a commitment to remaining in the territory (especially those who are most dependent on tourism), focusing their activities on livestock farming, construction work within the district, and charcoal-making in a complementary and controlled way. However, they recognise that unless charcoal-making is limited, it will destroy the environment.

They also point to the potential effect of a structural change within the SES on the community itself, and the extent to which it would not only involve an economic crisis but also a crisis in local 
organisation (governance). They recognise that tourism is not just an economic activity, but that it sustains the entire community as an organisational entity and with regard to the management of resources. Some of them even doubt whether the community could be maintained if there is a crisis in tourism: "People would end up fighting among themselves, each one would fight for their own interests ... Without tourism, there would be nothing" (R, H7), whereas others see community organisation as being crucial to the survival of the community: " ... we should all continue together, because if we are disorganised, they might come from the park and try to evict us, if we each go our separate ways ... we won't have the power to defend ourselves individually. When something is united between all of us, communal to all of us, we can withstand it" (M, H13).

The decline in the birth rate, the increase in pluri-activity and the development of subsistence food production for self-consumption are strategic practices in which new households are spearheading the desired configuration of the SES. The same is true with regard to picking/gathering, construction, and tourism (see Table 4). In this group, levels of participation in community life (governance) and place attachment are consistent, as are their levels of knowledge about the socio-environmental surroundings and their capacity for learning. Furthermore, members of these households propose analysis, expectations and strategies with regard to potential socio-environmental crises. Accordingly, it could be said that from a human agency perspective, the current configuration of the SES and its resilience should not undergo any dramatic changes in the short to medium term in light of the practices of these households (almost a third of the total), which should have a considerable influence on shaping its evolution.

However, the data recorded with regard to charcoal-making cast doubt upon the previous statement: new households are not stamping out this practice, instead they are accentuating it, adopting a behaviour that is moving in the opposite direction to the other households that make up the SES. This is not a trivial finding, given the significance and effects of this productive activity on the environment. A more dynamic and micro-reading of this practice will not only clarify its significance within the SES but will also, paradoxically, reveal one of the pillars of its resilience.

\section{Discussion: Considering the Plasticity of SES for a Better Understanding of Resilience}

Following the eradication of hunting and timber extraction, charcoal-making is the most negative environmental practice in Agua Blanca. The national park and the community itself have focused their efforts on eradicating it because of the impact it has on biodiversity and erosion in the valley. Charcoal production declined by 42.2\% between 2006 (3896 sacks) and 2017 (2253 sacks), even though its price quadrupled within that same period. In 2006, only eight households obtained more than $40 \%$ of their income through charcoal. By 2017, this had fallen to six, but four of these were new households. Does this point to a reversal of the trend? Are young people returning to charcoal-making as an activity? Does this question the current configuration of the SES and its resilience? It would be impossible to understand the significance of this fact without a process analysis that takes into consideration the structure of the SES and also focuses on the trajectory of households and their practises (human agency), by applying a dynamic and micro-level approach. As we shall see, the decisions made by households regarding economic tactics and the extraction of resources will help us to understand some of the strategic keys to the functioning of the SES.

For the people of Agua Blanca, charcoal is one of the resources provided by their forests, which should be exploited as little as possible. Tourism, first and foremost, is available to replace this profitable activity, followed by any other remunerated activity, within or outside of the community. They are intolerant of anyone who could carry out another activity but instead chooses to make charcoal, and there is great horizontal pressure/control in this regard. In 2017, out of all the consolidated households, only two-made up of older people — engaged in charcoal-making as their primary activity, and the other four combined it with tourism, in line with the community policy to eradicate charcoal making. So why do these new households engage in this activity? 
Studying their trajectories in detail, we see that all of them have engaged in charcoal-making during their education and training, that this activity is a bridge to others, and that those who use this activity to support themselves are in a precarious economic situation. In fact, practically all the adults in the community started out working in charcoal-making before moving on to tourism. For them, charcoal-making is part of their male rite of passage to adulthood, and young people simply reproduce the path followed by their elders who, prior to tourism, were dedicated solely to charcoal-making. This trend is not likely to change substantially, since it is the easiest and most obvious economic strategy available to young people, and there is also a clear demand for charcoal in the region. It is in this sense that we use the concept of a rite of passage to adulthood, metaphorically, applied to the economic independence of new households. Following on with this trajectory, new households start to engage in tourist activity when they have their first child and they need to earn more money. Those who do not have this opportunity are trapped in charcoal-making, which they move in and out of depending on their employment opportunities.

“Aged 18 I got engaged and I had to start making charcoal even though I didn't particularly like it. I did that for 3 or 4 years because I didn't know many people in PL (capital of the canton) to get any work. Then I was working in construction with the army, and now I mostly work in that. I only make charcoal now when there's nothing else to do." (M, H9)

"When there's work elsewhere I stop making charcoal, like when it's time to harvest barbasco. I would stop making charcoal if there was other work. I have to do it to survive." (J, H12)

All the young members of the community know how to make charcoal, and this knowledge, together with the resource itself, enhances the resilience of households when they are facing economic difficulty. Although there is a strong system of horizontal control to eradicate it, it cannot be disregarded as an emergency domestic strategy in case of necessity, or when a new household is formed.

Close attention must be paid to the symbolic and economic significance of a resource for the locals, since this significance will shape their strategies and preferences in the management of resources and in their perceptions of risk and crisis [40]. However, the decision to make or not make charcoal highlights the effect of human agency on the SES. Members of the community should not be understood as subjects who are mechanically determined to carry out certain productive practices. Their pluri-activity is based on an exercising of choice and decision-making, conditioned by opportunities or personal abilities but not determined completely by the configuration of the social-ecological system. Households exercise their agency by choosing which activities to carry out, and this holds true not only for those who are in a situation of vulnerability and cannot find any resources other than charcoal, but also for those who are looking to earn more money by making charcoal as well (even if they have other sources of income). Furthermore, agency is shown very clearly in decisions about when to start making charcoal and when to stop making it, and it is also expressed in the assembly meetings at which members sometimes debate the amount of charcoal being made in the community, its justification or lack thereof, and the fact that certain households are making charcoal is either tolerated or criticised. In these cases, the members of the community express opinions and make collective decisions about the use of environmental resources, even offering alternatives to those who make charcoal because they have no other possibility. Ultimately, the level of charcoal made is the consequence of different degrees of exercising human agency within the community. Under no circumstances is it a mechanical and structural response. This leads us to infer that it is a practice that strengthens the capacity for resilience, even though it is ostensibly contrary to the desirable configuration of the SES.

Therefore, this microanalysis conducted at the level of individual households shows that charcoal-making is an ambivalent activity. Although a conventional and simplified interpretation at the level of the SES as a whole might understand it as an unsustainable activity, if we focus the level of analysis on individual households, we see that, paradoxically, it could be a resilient practice for the social-ecological system if it is kept under control, in spite of the trade-off it entails. It is only possible to reach such a conclusion following a dynamic analysis that, together with the SES as a whole, 
contemplates individual households and their trajectories, in addition to the strict rules imposed by the community itself on the use of this resource.

Charcoal-making is a basic practice to understand the SES and its resilience, not only because of its biophysical effect but also on account of its socioeconomic role. The practice of this activity obeys not only structural criteria but also the decisions, tactics and strategies (human agency) applied within households in difficult circumstances and trajectories, and which express the adaptability of the SES and its potential transformability. All of this becomes patent when all the practices of households are tied together: from birth rate to place attachment, by way of collective participation. Hence, a context is shaped in which charcoal occupies a very specific place within the dynamic of the SES. Seen from this perspective, new households in Agua Blanca are privileged agents in maintaining the configuration of the SES and also with regard to its resilience, and charcoal-making-stigmatised and controlled but accepted by the community - is a strategic practice in this regard. On the one hand, it is fundamental to the resilience of households themselves (vulnerable situations), but on the other hand, by making them more resilient, it also contributes to the resilience of the SES in general by facilitating the progressive integration of new households into the desirable functioning of the SES. It is, therefore, the analysis of practices that will help us to understand one of the pillars of resilience in Agua Blanca: charcoal-making.

By conducting our analysis at a household level, we are able to uncover the internal plasticity of the SES: the variability and heterogeneity of the human behaviour that configures the system. The study of new households reveals their divergent and convergent behaviour with regard to the community as a whole in strategic aspects for the resilience of the social-ecological system. At the same time, it shows the inherent internal variability of the practices of young people. Accordingly, from a process perspective, we can unravel the significance of a specific activity-in this case charcoal-making-in a dynamic way, moving away from more static and mechanical visions resulting from a structural reading that would prevent us from capturing its complex role in the functioning and resilience of the SES. A simplistic and mechanical perspective would only be capable of noting that, for the park and the community itself, charcoal-making is a prohibited activity on account of its negative environmental impact. It would be impossible to discern the logic that maintains it as a possible activity and the processes whereby households are able to engage in it.

A perspective that considers human agency-the behaviour of the young people who make up new households-as an inherent part of the configuration of the SES helps us to understand the role of individual and collective decisions about when and under what conditions it is possible to implement activities and practices that endanger the desirable configuration of the SES and, accordingly, carry negative connotations. Paradoxically, these stigmatised activities can develop a crucial role in the resilience of new households-making their permanence and resistance in the territory viable in moments of vulnerability-, and, by extension, of the SES as a whole. Charcoal-making is a resilience factor for new households, but it could have a negative effect for the resilience of the SES as a whole. This will depend on the total number of households that have to make charcoal in order to survive, which would constitute a trade-off for the resilience of the whole SES. Therefore, charcoal-making would be subject to specific thresholds at any given time and would be bound by changes in its regulation. It is easy to reach the conclusion that resilience is inherently linked to practices. It is not just a capacity of the SES (from a general and abstract perspective), rather it is embodied in the everyday practices of households.

\section{Conclusions}

A social-ecological analysis that, through practices, links the systemic level with the household approach sheds light on the complexity of the way a SES functions, by offering a more in-depth and detailed perspective on its dual social-ecological nature. Furthermore, it helps us to understand and evaluate the evolution of social-ecological resilience, taking into account a dynamic agency-oriented perspective on desired futures [20]. 
In this regard, we cannot neglect the potential offered by an ethnographic approach, which provides a more in-depth understanding of everyday life in the SES. Evidently, any ethnographic study must be developed from an interdisciplinary perspective that considers sociological and cultural changes, economic development and spatial dynamics. From this perspective, ethnography affords us a much better understanding of the trajectory, significance and role of each productive activity, whilst also revealing the heterogeneity of the community and the performance of its households. To reach this level of knowledge, we must bear in mind that ethnography is not the mere deployment of a collection of qualitative research tools, rather, it is also based on a specific form of interaction between researchers and the population they are working with, based on mutual trust, opening up access to private contexts (observation) and information that only becomes available following long periods of coexistence, forging a consistent bond between researchers and the community. In order to develop this strategy effectively, research must adopt a longitudinal and multi-level approach, which will allow us to reflect on the configuration and dynamic of the SES and approach the role of human agency within it.

Having studied the case of Agua Blanca from a structural and phenomenological perspective, following an ethnographic methodology, we believe that this strategy offers a more complete and complex approach to social-ecological resilience for a number of different reasons. Firstly, it allows us to reflect the plasticity of the SES, since it reveals ambivalent processes and tactics, with paradoxical interpretations that are hard to capture through perspectives that focus on a single level of analysis: this is the case of charcoal-making activity in Agua Blanca. Secondly, because it clearly shows the balance between structure and agency found in the functioning of an SES: there are social-ecological configurations, whilst households generate anomalies that paradoxically contribute to their functioning. Finally, and most importantly, this strategy has the capacity to illustrate how resilience is linked not only to systemic trends, but also to social practices developed within the SES, hence resilience can be considered as practice.

The aim of this case study is not only to show the potential of a particular analytical perspective. It also contributes to a field of enquiry that should be broadened, working further on ascertaining whether considering resilience as practice is useful, and whether a household approach is appropriate for its study. However, it also shows us its limitations, particularly those derived from the size of the SES that can be studied from this perspective, and therefore pertaining to the need to explore practices beyond community contexts, in more heterogeneous social spheres. It would also be advisable to corroborate the advantages of applying this household approach to social-ecological systems that present an undesirable configuration in order to understand and transform their frameworks of social-ecological interactions.

Author Contributions: Investigation, Formal analysis, Methodology and Writing - original draft, E.R.-B. and P.R.-B.; Funding acquisition, Project administration and Writing - review \& editing, E.R.-B.

Funding: This work was supported by the MINECO, Spain; under grant CSO2017-84893-P.

Conflicts of Interest: The authors declare no conflict of interest.

\section{References}

1. Folke, C.; Biggs, R.; Norström, A.V.; Reyers, B.; Rockström, J. Social-ecological resilience and biosphere-based sustainability science. Ecol. Soc. 2016, 21, 41. [CrossRef]

2. Armitage, D.; Johnson, D. Can Resilience be Reconciled with Globalization and the Increasingly Complex Conditions of Resource Degradation in Asian Coastal Regions? Ecol. Soc. 2006, 11, 2. [CrossRef]

3. Booher, D.E.; Innes, J.E. Governance for resilience: CALFED as a complex adaptive network for resource management. Ecol. Soc. 2012, 15, 35. [CrossRef]

4. Anderies, J.M.; Folke, C.; Hatfield-Dodds, S.; Hughes, T.P.; Lebel, L.; Campbell, B.; Wilson, J. Governance and the Capacity to Manage Resilience in Regional Social-Ecological Systems. Ecol. Soc. 2006, 11, 19. 
5. Olsson, P.; Folke, C.; Berkes, F. Adaptive co-management for building resilience in social-ecological systems. Environ. Manag. 2004, 34, 75-90. [CrossRef] [PubMed]

6. Robards, M.D.; Schoon, M.L.; Meek, C.L.; Engle, N.L. The importance of social drivers in the resilient provision of ecosystem services. Glob. Environ. Chang. 2011, 21, 522-529. [CrossRef]

7. Boonstra, W.J. Conceptualizing power to study social-ecological interactions. Ecol. Soc. 2016, $21,21$. [CrossRef]

8. Brown, K. Global environmental change. I: A social turn for resilience? Prog. Hum. Geogr. 2013, 38, 107-117. [CrossRef]

9. Cote, M.; Nightingale, A.J. Resilience thinking meets social theory: Situating social change in socio-ecological systems (SES) research. Prog. Hum. Geogr. 2012, 36, 475-489. [CrossRef]

10. Coulthard, S. Can we be both resilient and well and what choices do people have? Incorporating agency into the resilience debate from a fisheries debate. Ecol. Soc. 2011, 17, 4. [CrossRef]

11. Fabinyi, M.; Evans, L.; Foale, S. Social-ecological systems, social diversity, and power: Insights from anthropology and political ecology. Ecol. Soc. 2014, 19, 28. [CrossRef]

12. Hatt, K. Social Attractors: A Proposal to Enhance "Resilience Thinking" about the Social. Soc. Nat. Resour. 2013, 26, 30-43. [CrossRef]

13. Hornborg, A. Zero-sum world: Challenges in conceptualizing environmental load displacement and ecologically unequal exchange in the world-system. Int. J. Comp. Sociol. 2009, 50, 237-262. [CrossRef]

14. Olsson, L.; Jerneck, A.; Thoren, H.; Persson, J.; O’Byrne, D. Why resilience is unappealing to social science: Theoretical and empirical investigations of the scientific use of resilience. Sci. Adv. 2015, 1, e1400217. [CrossRef]

15. Turner, M.D. Political ecology I: An alliance with resilience? Prog. Hum. Geogr. 2014, 38, 616-623. [CrossRef]

16. Vayda, A.P.; Walters, B.B. Against Political Ecology. Hum. Ecol. 1999, 27, 167-179. [CrossRef]

17. Alinovi, L.; Caron, P.; Kautsky, E.E.; Fortmann, L.; Quinlan, A.; Staver, C.; Bousquet, F.; Botta, A.; Barreteau, O.; Bossio, D.; et al. Resilience and development: Mobilizing for transformation. Ecol. Soc. 2016, 21, 40.

18. McGinnis, M.D.; Ostrom, E. Social-ecological system framework: Initial changes and continuing challenges. Ecol. Soc. 2014, 19, 30. [CrossRef]

19. Brown, K.; Westaway, E. Agency, Capacity, and Resilience to Environmental Change: Lessons from Human Development, Well-Being, and Disasters. Annu. Rev. Environ. Resour. 2011, 36, 321-342. [CrossRef]

20. Brown, K. Resilience, Development and Global Change; Routledge: London, UK, 2016.

21. Davidson, D.J. The Applicability of the Concept of Resilience to Social Systems: Some Sources of Optimism and Nagging Doubts. Soc. Nat. Resour. 2010, 23, 1135-1149. [CrossRef]

22. Ostrom, E. Governing the Commons: The Evolution of Institutions for Collective Action; Cambridge University Press: New York, NY, USA, 1990.

23. Ostrom, E. Institutional Diversity of Commons. In Encyclopedia of Biodiversity; Academic Press: Cambridge, MA, USA, 2001; Volume 1.

24. Ostrom, E.; Gardner, R.; Walker, J.M. Rules, Games, and Common-Pool Resources; University of Michigan Press: Ann Arbor, MI, USA, 1994.

25. De Certau, M. L'Invention du Quotidien I. Arts de Faire; Gallimard: Paris, France, 1990.

26. Cortes-Vazquez, J.A.; Ruiz-Ballesteros, E. Practicing Nature: A phenomenological rethinking of environmentality in natural protected areas in Ecuador and Spain. Conserv. Soc. 2018, 16, $232-242$. [CrossRef]

27. Biggs, R.; Schlüter, M.; Biggs, D.; Bohensky, E.L.; BurnSilver, S.; Cundill, G.; Dakos, V.; Daw, T.M.; Evans, L.S.; Kotschy, K.; et al. Toward Principles for Enhancing the Resilience of Ecosystem Services. Annu. Rev. Environ. Resour. 2012, 37, 421-448. [CrossRef]

28. Carpenter, S.R.; Arrow, K.J.; Barrett, S.; Biggs, R.; Brock, W.A.; Crépin, A.-S.; Engström, G.; Folke, C.; Hughes, T.P.; Kautsky, N.; et al. General Resilience to Cope with Extreme Events. Sustainability 2012, 4, 3248-3259. [CrossRef]

29. Armitage, D.; Berkes, F.; Doubleday, N. Introduction: Moving beyond co- management. In Adaptive Co-management. Collaborations, Learning and Multi-level Governance; Armitage, D.F., Berkes, F., Doubleday, N., Eds.; University of British Columbia Press: Vancouver, BC, Canada, 2007; pp. 1-18. 
30. Zwiers, S.; Markantoni, M.; Strijker, D. The role of change- and stability-oriented place attachment in rural community resilience: A case study in south-west Scotland. Community Dev. J. 2016, 53, 281-300. [CrossRef]

31. Agrawal, A. Environmentality; Technologies of Government and the Making of Subjects; Duke University Press: Durham, UK, 2005.

32. Poteete, A.R.; Jansen, M.; Ostrom, E. Working Together: Collective Action, the Commons, and Multiple Methods in Practice; Princeton University Press: Princeton, NJ, USA, 2010.

33. Yin, R.K. Case Study Research; Design and Methods; Sage Publications: Thousand Oaks, CA, USA, 1994.

34. Faulkner, L.; Brown, K.; Quinn, T. Analyzing community resilience as an emergent property of dynamic social-ecological systems. Ecol. Soc. 2018, 23, 24. [CrossRef]

35. Ruiz-Ballesteros, E. Agua Blanca; Comunidad y turismo en el Pacífico ecuatorial; Abya-yala: Quito, Ecuador, 2009.

36. Ruiz-Ballesteros, E. Socio-ecological resilience and community-based tourism. An approach from Agua Blanca, Ecuador. Tour. Manag. 2011, 32, 655-666. [CrossRef]

37. Ruiz-Ballesteros, E.; Gual, M.A. The emergence of new commons. Community and multi-level governance in the Ecuadorian coast. Hum. Ecol. 2012, 40, 847-862. [CrossRef]

38. Berkes, F.; Seixas, C. Building resilience in Lagoon socio-ecological systems: a local-level perspective. Ecosyst 2005, 8, 967-974. [CrossRef]

39. Folke, C. Socio-ecological resilience and behavioural responses. In Individual and Structural Determinants of Environmental Practice; Biel, A., Hansson, B., Mårtensson, M., Eds.; Ashgate Publishers: London, UK, 2003; pp. 226-287.

40. Quinn, T.; Bousquet, F.; Guerbois, C.; Heider, L.; Brown, K. How local water and waterbody meanings shape flood risk perception and risk management preferences. Sustain. Sci. 2019, 14, 565-578. [CrossRef]

(C) 2019 by the authors. Licensee MDPI, Basel, Switzerland. This article is an open access article distributed under the terms and conditions of the Creative Commons Attribution (CC BY) license (http://creativecommons.org/licenses/by/4.0/). 